\title{
Increasing the production of gas condensate by using ammonium carbonate salts
}

\author{
Viktoriia Dmytrenko ${ }^{1,}{ }^{*}$, Ivan Zezekalo ${ }^{1}$, Yuriy Vynnykov ${ }^{1}$, Nikolay Hristov ${ }^{2}$, and Gergana Meracheva ${ }^{2}$ \\ ${ }^{1}$ National University «Yuri Kondratyuk Poltava Polytechnic», Department of Oil and Gas Engineering and Technology, \\ 24 Pershotravnevyi Ave., Poltava, 36011, Ukraine \\ ${ }^{2}$ University of Mining and Geology «St. Ivan Rilski», Faculty of Geology and Exploration, 1 Prof. Boyan Kamenov Str., Sofia, \\ Bulgaria
}

\begin{abstract}
The work is devoted to the problem of increasing gas condensate production in gas condensate fields. It was found that ammonium carbonate salts, in the absence of calcium chloride type waters, interact with carbonate rocks, increase the permeability of reservoirs. Solutions of ammonium carbonate salts when interacting with formation water of the calcium chloride type form chemically precipitated chalk in the pore space, while the permeability of carbonate rocks decreases. A set of experimental studies was carried out to study the displacing and washing properties of ammonium carbonate salts. It was found that ammonium carbonate salts have high displacing properties, the displacement ratio of kerosene by $\mathrm{NH}_{4} \mathrm{HCO}_{3}$ solution is $0.75-0.80$, while reservoir water $-0.55-0.58$. According to the results of laboratory studies of the displacing and washing characteristics of ammonium carbonate salts, conclusions were made about the effect of bicarbonate solution (ammonium carbonate salts) on the production characteristics of a well in reservoir conditions at temperatures of $80-100{ }^{\circ} \mathrm{C}$ and above. Industrial tests of ammonium carbonate salts showed an increase in gas flow by 30-50\% at wells № 23 of Opishnia, № 115 of Mashivka, № 3 of Tymofiivka gas condensate fields. The effect of formation treatment with ammonium carbonate salts is achieved due to clearing of well bottom zone and increasing the formation permeability. At wells № 56, 108 of Yablunivka and № 58 of Tymofiivka gas condensate fields, an increase in the condensate ratio was observed by 22$35 \%$. The effectiveness of this treatment is associated with the simultaneous bottomhole zone cleaning from asphalt-resinous contaminants and permeability increase, as well as with the hydrophilization of the pore space and mobility increase of condensate precipitated as a result of carbon dioxide effect, which was rejected as a result of decomposition of ammonium carbonate. Thus, experimental and industrial tests in Opishnia, Mashivka, Tymofiivka, Yablunivka gas condensate fields of Poltava region confirmed the effectiveness of using ammonium carbonate to increase hydrocarbon production. The prospect of further research is aimed at developing a technology for increasing the production of liquid hydrocarbons by using ammonium carbonate salts.
\end{abstract}

\section{Introduction}

Ukraine has significant deposits of developed mineral deposits. To date, 90 types of minerals have been explored, which are concentrated in almost 8000 deposits. For sustainable development it is necessary to increase the efficiency of natural resources $[1,2,3]$.

Today, most of the gas, gas condensate and oil fields in Ukraine are at the final stage of development, the production of gas and liquid hydrocarbons is decreasing.

One of the urgent problems of the oil and gas industry is to improve the efficiency of wells operation. In modern conditions, the solution to this problem is largely determined by the timely development, justification and targeted application of new technologies to improve the efficiency of hydrocarbon extraction.

The development of gas condensate fields for depletion is accompanied by a decrease in reservoir pressure and retrograde condensation of high-boiling $C 5+$ hydrocarbons (condensate) with the loss of some of them into the liquid phase and their loss in the reservoirs, due to the fact that the condensate that precipitates in the reservoirs turns out to be stationary and is not involved in filtration processes.

As a result, up to $30-60 \%$ of the initial condensate reserves remain in the deposits [4-6]. In addition, there is clogging of the pores with rock particles, asphalt, resin, paraffin deposits [7-9].

Therefore, the search and substantiation of new methods of field development aimed at increasing the condensate recovery of the productive formation, at the same time, will ensure the cleaning of the bottomhole zone from pollution products and this is an urgent task.

At the first stage of development of oil and gas condensate fields, production is carried out due to the depletion of reservoir energy. This stage, called primary,

\footnotetext{
* Corresponding author: dmytr.v@gmail.com
} 
makes it possible to extract from the underground reservoir only up to $10-25 \%$ of hydrocarbons [10]. The various methods developed later were primarily aimed at maintaining reservoir pressure - methods of secondary production, or to improve the conditions for the movement of hydrocarbons in the porous environment of the rock - methods of tertiary production. The latter include various approaches to increasing the recovery of liquid hydrocarbons from depleted and highly watered fields.

These methods and their variations, according to some estimates [11], have up to 250 names, including various schemes for the formation of excess pressure, injection of working media, thermal effects on the formation, chemical treatment of productive reservoirs, and the like.

One of the most effective ways to increase the recovery of liquid hydrocarbons from reservoirs is to inject water and $\mathrm{CO}_{2}$ into the well [11-13]. With regard to the prospects for using the method of injecting carbon dioxide into the reservoir to increase oil and condensate recovery of depleted and highly watered fields, let us focus on the influence of the factor of carbon dioxide dissolution in water. Firstly, an aqueous solution of $\mathrm{CO}_{2}$, entering into reactions and dissolving individual constituents of the rock, increases the permeability of the porous reservoir. Secondly, the viscosity of water increases, which leads to a decrease in its mobility, and together with an increase in the mobility of liquid hydrocarbons (through the dissolution of carbon dioxide in them), this contributes to the equalization of the mobility of water and liquid hydrocarbons, which is important for the efficiency of the process. Finally, changes in the properties of water and liquid hydrocarbons cause a decrease in the surface tension at «liquid hydrocarbons-water» interface and increase the wettability of the rock with water. All this in combination contributes to a more efficient washout of the hydrocarbon film. [14, 15].

According to 2000 estimates, there were 84 projects to enhance condensate and oil recovery by carbon dioxide injection in the world at the stage of implementation. Of these, 72 (96\%) were carried out in the United States, which indicates its leadership in this important scientific and technological area. It is interesting that in work [16] the second place is given to Turkey, whose projects, according to expert estimates, allow counting on significant commercial success [16]. According to estimates, in 2014, 136 carbon dioxide injection projects are being implemented worldwide, carried out by 30 operators. Of these, 88 are considered successful, 18 are promising projects, the remaining 20 have recently started [17].

The use of carbonized water to enhance condensate and oil recovery is also known. The main advantage of the injection of carbonized water is the relatively low consumption of carbon dioxide during injection into the reservoir in comparison with other options for its use [18].

However, in both cases, pure liquefied carbon dioxide, a compressor, and special equipment for injecting liquefied gases and liquids saturated with gas at high pressures are required.
Based on the above, it can be assumed that a reagent containing $10-15 \%$ of chemically bound $\mathrm{CO}_{2}$, which is release under formation conditions, can be highly effective.

Such a reagent is a salt of carbonate (carbonic) acid $\mathrm{H}_{2} \mathrm{CO}_{3}$, namely, bicarbonate and ammonium carbonate $\left(\mathrm{NH}_{4} \mathrm{HCO}_{3}\right.$ and $\left(\mathrm{NH}_{4}\right)_{2} \mathrm{CO}_{3}$ respectively). Solutions of these salts decompose easily at temperatures of $40-90{ }^{\circ} \mathrm{C}$. Therefore, in some cases, it is more reasonable from an economic point of view to use reagents containing 10$15 \%$ of chemically bound carbon dioxide $\mathrm{CO}_{2}$, which is released in reservoir conditions.

The aim of the work is to study the effect of ammonium carbonate on the filtration properties of the reservoir, displacing and washing out the properties of the solution of ammonium carbonate and the use of a new reagent to increase condensate recovery at the fields of the Dnieper-Donetsk basin.

\section{Materials and methods}

The object of the study is a $20 \%$ concentration of ammonium bicarbonate (ammonium carbonate) solution.

The influence of solutions of ammonium carbonate salts on the physical and lithological parameters of core samples, namely: permeability, porosity, size of pore channels, were studied at the UIPK-1M installation, for which the natural core was filled with ammonium carbonate salts at a concentration of $200 \mathrm{~g} / 1$ at temperatures $30,40,50,60,70^{\circ} \mathrm{C}$ for 3 hours.

Core material from various oil and gas fields (Khukhra, Reshetniaky, Rybalske, Velyki Bubny, Novohryhorivka and Matlakhivka) was used as reservoir models that were studied, namely, sandstone samples of 15 pcs. with the diameter of $30 \mathrm{~mm}$ and length $30 \mathrm{~mm}$, with a permeability of $0.051-1.320 \mu^{2}$ and open porosity, which was in the range of $9.5-22.7 \%$. Table 1 shows the geography of the studied samples.

Permeability was determined on a stationary laboratory setup with a fixed side hydraulic compression of $3 \mathrm{MPa}$.

Ammonium carbonate salts were removed from the core samples: in one case - with distilled water, in another - with formation water. The completeness of washing was determined by the presence of ammonium and carbonate ions in the filtrate by the titrimetric method.

The displacing properties of ammonium carbonate salts were determined by the value of phase permeability in the core samples. Phase permeability was investigated on the UIPK-1M installation at temperatures of 20, 30, 40, $50,60^{\circ} \mathrm{C}$.

The washing properties of the solution of ammonium carbonate salts were investigated as follows: during the experiments, a sample of asphaltene substances (AS) dissolved in acetone, which were taken from the Yablunivka gas condensate field, was placed in the studied formation model. Acetone was removed by heating the test layer to $45^{\circ} \mathrm{C}$.

After that, the formation model was washed with a solution of ammonium carbonate with a volume concentration of $20 \%$. After each washing, the formation 
model was dried in a drying oven and the content of asphalt-resinous substances was determined by the gravimetric method. For comparison, another formation model was washed with formation water.

Table 1. Geography of the studied core samples.

\begin{tabular}{|c|c|c|c|}
\hline $\begin{array}{c}\text { Core } \\
\text { sample } \\
\text { № }\end{array}$ & $\begin{array}{c}\text { The field where } \\
\text { core samples taken }\end{array}$ & $\begin{array}{c}\text { Well } \\
\text { № }\end{array}$ & $\begin{array}{c}\text { Selection } \\
\text { interval } \\
\boldsymbol{h} \\
\mathbf{m}\end{array}$ \\
\hline 4802 & Khukhra & 9 & $2931-2988$ \\
\hline 4805 & Khukhra & 9 & $2931-2988$ \\
\hline 4809 & Khukhra & 9 & $2931-2988$ \\
\hline 4814 & Khukhra & 9 & $3046-3053$ \\
\hline 4837 & Novohryhorivka & 100 & $3693-3697$ \\
\hline 4844 & Novohryhorivka & 100 & $3693-3697$ \\
\hline 4838 & Novohryhorivka & 100 & $3693-3697$ \\
\hline 4873 & Matlakhivka & 36 & $3577-3584$ \\
\hline 5021 & Reshetniaky & 65 & $2359-2367$ \\
\hline 5023 & Reshetniaky & 65 & $2359-2367$ \\
\hline 5027 & Reshetniaky & 65 & $2359-2367$ \\
\hline 4410 & Velyki Bubny & 114 & $2921-2929$ \\
\hline 4414 & Velyki Bubny & 114 & $2929-2936$ \\
\hline 4416 & Velyki Bubny & 114 & $2929-2936$ \\
\hline 5114 & Rybalske & 206 & $4284-4294$ \\
\hline
\end{tabular}

\section{Research results}

The results of studying the effect of ammonium carbonate solutions on the physical and lithological parameters of core samples are shown in Table 2, 3 .

Analysis of the data shows that the samples, from which ammonium carbonate salts were removed by distilled water, increased the permeability value by an average of $18 \%$ relative to the initial values. The theoretical size of the pore channels also increased in all studied core samples.

In addition, the effect of $\mathrm{NH}_{4} \mathrm{HCO}_{3}$ solution on the carbonate content of the samples is observed. In almost all cores, it decreased by $47-52 \%$ from the initial values (Table 2). As a result of the experiments, it can be argued that the dissolution of carbonate cements with ammonium salts occurs according to the equation.

$$
\begin{gathered}
2 \mathrm{NH}_{4} \mathrm{HCO}_{3} \rightarrow\left(\mathrm{NH}_{4}\right)_{2} \mathrm{CO}_{3}+\mathrm{H}_{2} \mathrm{CO}_{3} \\
\mathrm{H}_{2} \mathrm{CO}_{3} \rightarrow \mathrm{CO}_{2}+\mathrm{H}_{2} \mathrm{O} \\
\mathrm{CaCO}_{3}+\mathrm{CO}_{2}+\mathrm{H}_{2} \mathrm{O} \rightarrow \mathrm{Ca}\left(\mathrm{HCO}_{3}\right)_{2}
\end{gathered}
$$

In this case, insoluble $\mathrm{CaCO}_{3}$ converted into soluble $\mathrm{Ca}\left(\mathrm{HCO}_{3}\right)_{2}$.

\begin{tabular}{|c|c|c|c|c|c|c|c|c|}
\hline \multirow{2}{*}{$\begin{array}{c}\text { № } \\
\text { Core } \\
\text { sample }\end{array}$} & \multicolumn{3}{|c|}{ Initial parameters } & \multicolumn{3}{|c|}{ Final parameters } & \multicolumn{2}{|c|}{ Carbonation $K, \%$} \\
\hline & $\begin{array}{c}\text { Permeability } \\
k \\
10^{-15} \mathrm{~m}^{2} \\
\end{array}$ & $\begin{array}{c}\text { Porosity } \\
n \\
\% \\
\end{array}$ & $\begin{array}{c}\text { Pore size } \\
\boldsymbol{l} \\
\mu \mathrm{m}\end{array}$ & $\begin{array}{c}\text { Permeability } \\
k \\
10^{-15} \mathrm{~m}^{2} \\
\end{array}$ & $\begin{array}{c}\text { Porosity } \\
n \\
\% \\
\end{array}$ & $\begin{array}{c}\text { Pore size } \\
l \\
\mu \mathrm{m}\end{array}$ & Before & After \\
\hline 4802 & 940 & 20.8 & 19.0 & 1030 & 22.9 & 17.3 & 1 & 0.5 \\
\hline 4805 & 1050 & 22.1 & 20.9 & 1326 & 22.6 & 18.4 & 3.3 & 1.6 \\
\hline 4809 & 620 & 21.1 & 17.3 & 867 & 17.9 & 15.8 & 2.8 & 1.4 \\
\hline 4814 & 42 & 14.2 & 5.4 & 57 & 11.8 & 5.0 & 3.1 & 1.6 \\
\hline 4837 & 166 & 20.8 & 24.9 & 172 & 20.6 & 23.1 & 14 & 11 \\
\hline 4844 & 46 & 9.9 & 6.9 & 64 & 9.6 & 5.9 & 9 & 7 \\
\hline 5021 & 1292 & 22.7 & 20.4 & 1341 & 23.0 & 20.6 & 0.9 & 0.4 \\
\hline
\end{tabular}

Table 2. Change of physical and lithological parameters of core samples during their treatment with $\mathrm{NH}_{4} \mathrm{HCO}_{3}$ solution $\left(t=20^{\circ} \mathrm{C}\right)$ with subsequent removal of $\mathrm{NH}_{4} \mathrm{HCO}_{3}$ with distilled water.

\begin{tabular}{|c|c|c|c|c|c|c|}
\hline \multirow[b]{2}{*}{$\begin{array}{c}\text { № } \\
\text { Core } \\
\text { sample }\end{array}$} & \multicolumn{3}{|c|}{ Initial parameters } & \multicolumn{3}{|c|}{ Final parameters } \\
\hline & $\begin{array}{c}\text { Permeability } \\
k \\
10^{-15} \mathrm{~m}^{2}\end{array}$ & $\begin{array}{c}\text { Porosity } \\
n \\
\% \\
\end{array}$ & $\begin{array}{c}\text { Pore size } \\
\quad l \\
\mu \mathrm{m}\end{array}$ & $\begin{array}{c}\text { Permeability } \\
k \\
10^{-15} \mathrm{~m}^{2}\end{array}$ & $\begin{array}{c}\text { Porosity } \\
n \\
\% \\
\end{array}$ & $\begin{array}{c}\text { Pore size } \\
l \\
\mu \mathrm{m}\end{array}$ \\
\hline 4873 & 172 & 17.9 & 8.4 & 166 & 14.8 & 8.3 \\
\hline 5027 & 337 & 21.7 & 10.6 & 310 & 21.3 & 10.2 \\
\hline 4410 & 70 & 16.8 & 5.5 & 56 & 16.5 & 4.9 \\
\hline 4416 & 245 & 22.4 & 8.9 & 192 & 17.6 & 8.9 \\
\hline 4838 & 1038 & 21.8 & 18.6 & 890 & 18.5 & 18.6 \\
\hline 5023 & 366 & 18.8 & 11.7 & 345 & 18.1 & 10.8 \\
\hline 5114 & 51 & 10.4 & 6.0 & 40 & 10.2 & 5.3 \\
\hline 5119 & 63 & 9.5 & 6.9 & 45 & 9.0 & 6.0 \\
\hline 4414 & 290 & 22.6 & 9.7 & 246 & 22.2 & 8.9 \\
\hline
\end{tabular}

Table 3. Change of physical and lithological parameters of core samples during their treatment with $\mathrm{NH}_{4} \mathrm{HCO}_{3}$ solution $\left(t=20^{\circ} \mathrm{C}\right)$ with subsequent removal of $\mathrm{NH}_{4} \mathrm{HCO}_{3}$ by formation water.

In the laboratory, a number of experiments were performed to dissolve dry chalk with $20 \%$ ammonium bicarbonate solution.

The results showed that under normal conditions, the solubility of $\mathrm{CaCO}_{3}$ in $\mathrm{NH}_{4} \mathrm{HCO}_{3}$ reaches $0.85-1.12 \mathrm{~g} / \mathrm{l}$, and at a temperature of $60^{\circ} \mathrm{C}-1.6-1.74 \mathrm{~g} / \mathrm{l}$. This indicates the solubility of carbonate cements, which contain a solution of ammonium bicarbonate in the core samples.

Based on the thermochemical conditions of this process, the solubility of carbonate cement will increase with increasing pressure, which is a positive characteristic 
of the effect of $\mathrm{NH}_{4} \mathrm{HCO}_{3}$ solution on carbonate rocks in formation conditions.

The second part of the core samples shown in Table 3, from which ammonium carbonate was removed by formation water, reduced the permeability value by 14$28 \%$, the size of the pore channels also decreased.

The reason for this effect of ammonium bicarbonate solution on the permeability of the core samples is obviously a chemical reaction between highly mineralized water and ammonium bicarbonate with the formation and precipitation of a solid phase.

Laboratory studies carried out when mixing formation waters from gas condensate wells with a $20 \%$ ammonium bicarbonate solution showed that when the content of $\mathrm{Ca}^{2}$ ${ }^{+}$and $\mathrm{Fe}^{3+}$ in the formation waters is more than $0.5 \mathrm{mg}-$ ion / 1, as well as $\mathrm{Mg}^{2+}-1.5 \mathrm{mg}$ - ion/l and more, the use of ammonium carbonate is ineffective due to the formation of water-insoluble carbonates according to the scheme.

$$
\begin{aligned}
& 2 \mathrm{NH}_{4} \mathrm{HCO}_{3}+\mathrm{CaCl}_{2} \rightarrow \mathrm{CaCO}_{3}+2 \mathrm{NH}_{4} \mathrm{Cl}+\mathrm{CO}_{2}+\mathrm{H}_{2} \mathrm{O} \\
& 2 \mathrm{NH}_{4} \mathrm{HCO}_{3}+\mathrm{MgCl}_{2} \rightarrow \mathrm{Mg}(\mathrm{OH})_{2}+2 \mathrm{NH}_{4} \mathrm{Cl}+2 \mathrm{CO}_{2}
\end{aligned}
$$

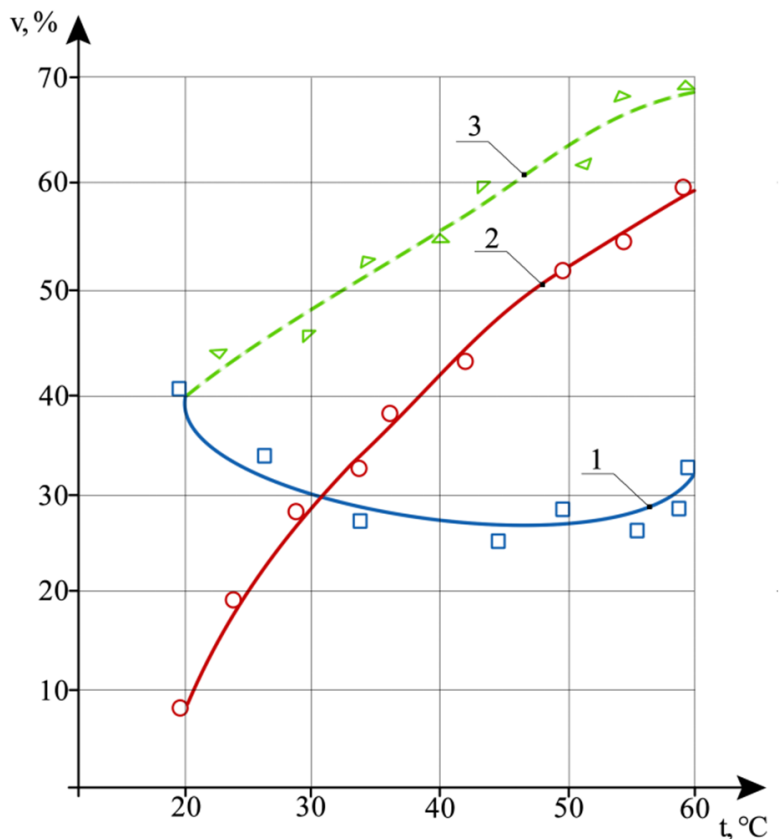

Fig. 1. Dependence of the relative permeability of core samples on temperature. Permeability: 1 - by solution of ammonium bicarbonate (in a sample of kerosene) 2 - by formation water (in a sample of kerosene), 3 - by air - (in a sample of kerosene).

Further research was aimed at studying the displacing properties of ammonium carbonate salts.

Table 4 shows the average values of the displacement coefficient, residual saturation, and relative permeability. From these data it follows that the relative permeability of the samples in descending order is as follows: At a temperature of $20^{\circ} \mathrm{C}$ :

1. by ammonium bicarbonate solution;

2. by air (in the kerosene sample);

3. by formation water (in the kerosene sample). At a temperature of $60{ }^{\circ} \mathrm{C}$ :

1. by air (in the kerosene sample);
2. by formation water (in the kerosene sample);

3. by ammonium bicarbonate (in the kerosene sample).

Based on the results of experiments for displacing kerosene from core samples, graphical dependencies were built, which are shown in Fig. 1 and 2.

The low phase permeability of the core with respect to ammonium bicarbonate confirms the well-known phenomenon of an increase in the viscosity of aqueous solutions when they are saturated with carbon dioxide. It is known [19] that with an increase in the concentration of $\mathrm{CO}_{2}$ in an aqueous solution up to $2.1 \%$, the viscosity increases by $18.9 \%$, and at a concentration of $\mathrm{CO}_{2}$ up to $5.6 \%$ - by $27.2 \%$.

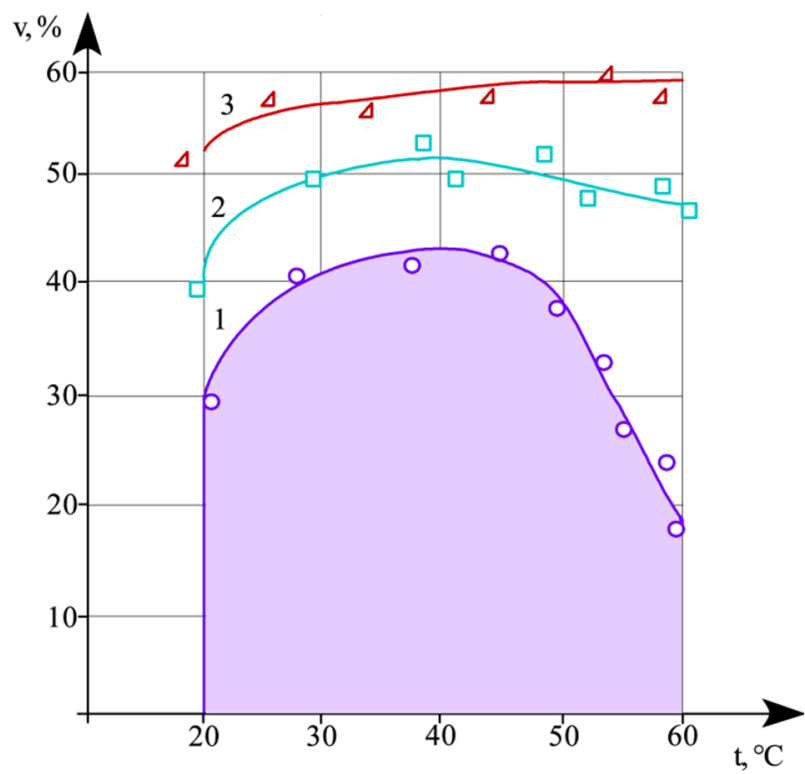

Fig. 2. Temperature dependence of the relative permeability of core samples. Displacement of kerosene from the core sample by: 1 - ammonium bicarbonate solution, 2 - formation water, 3 - air.

Analyzing the data shown in Fig. 2, it can be assumed that the increase in the temperature of the solution to 30 $40{ }^{\circ} \mathrm{C}$ causes the release of some carbon dioxide, which initially pollutes the carbonate solution, increasing its viscosity, and at the same time blocks the pore space (Joumen effect). This, in turn, leads to a decrease in the phase permeability of the core to ammonium bicarbonate and low displacement of $\mathrm{NH}_{4} \mathrm{HCO}_{3}$.

However, a further increase in the temperature of the solution to $50-60{ }^{\circ} \mathrm{C}$ leads to an intensive release of carbon dioxide, which is dissolved in kerosene, changing its physicochemical properties. Studies show that as the temperature rises, the kerosene yield increases and the phase permeability of the degassed ammonia solution increases.

Further research is aimed at studying the washing properties of a solution of ammonium carbonate salts. During the experiments, a sample of asphaltene sediments (AS) dissolved in acetone, which were isolated from the Yablunivka gas condensate field, was placed in the studied formation model. Acetone was removed by heating the studied formation to $45^{\circ} \mathrm{C}$. 
Table 4. The results of experiments to determine the coefficients of displacement, saturation and relative permeability.

\begin{tabular}{|c|c|c|c|c|c|c|c|c|}
\hline \multirow{3}{*}{ № } & \multirow{3}{*}{$\begin{array}{l}\text { Characteristics of the } \\
\text { experiment }\end{array}$} & \multirow{3}{*}{ Parameters } & \multicolumn{6}{|c|}{ The results of the experiment } \\
\hline & & & \multicolumn{6}{|c|}{ Experiment temperature, ${ }^{\circ} \mathrm{C}$} \\
\hline & & & 20 & 30 & 40 & 50 & 60 & 70 \\
\hline \multirow[t]{3}{*}{1.} & \multirow{3}{*}{$\begin{array}{l}\text { Displacement of kerosene by } \\
\text { ammonium bicarbonate } \\
\text { solution }\end{array}$} & $\begin{array}{l}\text { displacement } \\
\text { coefficient, } \beta\end{array}$ & 0.75 & 0.60 & 0.57 & 0.68 & 0.80 & - \\
\hline & & $\begin{array}{c}\text { saturation } \\
\text { coefficient, } k_{o}\end{array}$ & 0.25 & 0.40 & 0.43 & 0.32 & 0.20 & - \\
\hline & & $\begin{array}{c}\text { relative } \\
\text { permeability, } k_{i}\end{array}$ & 0.40 & 0.35 & 0.26 & 0.26 & 0.33 & - \\
\hline \multirow[t]{3}{*}{2.} & \multirow[t]{3}{*}{$\begin{array}{l}\text { Displacement of kerosene by } \\
\text { formation water }\end{array}$} & $\begin{array}{l}\text { displacement } \\
\text { coefficient, } \beta\end{array}$ & 0.60 & 0.50 & 0.48 & 0.50 & 0.55 & 0.60 \\
\hline & & $\begin{array}{c}\text { saturation } \\
\text { coefficient, } k_{o}\end{array}$ & 0.40 & 0.50 & 0.52 & 0.50 & 0.45 & 0.38 \\
\hline & & $\begin{array}{c}\text { relative } \\
\text { permeability, } k_{i}\end{array}$ & 0.11 & 0.28 & 0.42 & 0.54 & 0.58 & 0.62 \\
\hline \multirow[t]{3}{*}{3.} & \multirow[t]{3}{*}{$\begin{array}{l}\text { Displacement of kerosene by } \\
\text { air }\end{array}$} & $\begin{array}{l}\text { displacement } \\
\text { coefficient, } \beta\end{array}$ & 0.47 & 0.43 & 0.41 & 0.40 & 0.37 & - \\
\hline & & $\begin{array}{c}\text { saturation } \\
\text { coefficient, } k_{o}\end{array}$ & 0.53 & 0.57 & 0.59 & 0.60 & 063 & - \\
\hline & & $\begin{array}{c}\text { relative } \\
\text { permeability, } k_{i}\end{array}$ & 0.40 & 0.45 & 0.52 & 0.62 & 0.66 & - \\
\hline
\end{tabular}

Table 5. Influence of washing on the content of asphaltene sediments in the formation model.

\begin{tabular}{|c|c|c|c|c|c|c|}
\hline \multirow{4}{*}{$\begin{array}{l}\text { Temperature, } \\
{ }^{\circ} \mathbf{C}\end{array}$} & \multicolumn{6}{|c|}{ The content of asphaltene sediments, \% } \\
\hline & \multirow{2}{*}{\multicolumn{3}{|c|}{$\begin{array}{l}\text { Formation water } \\
\text { Washing number }\end{array}$}} & \multirow{2}{*}{\multicolumn{3}{|c|}{$\begin{array}{c}\text { 20th solution of } \mathrm{NH}_{4} \mathrm{HCO}_{3} \\
\text { Washing number }\end{array}$}} \\
\hline & & & & & & \\
\hline & 1 & 2 & 3 & 1 & 2 & 3 \\
\hline 20 & 86 & 79 & 53 & 12 & 4 & 0.1 \\
\hline 40 & 72 & 51 & 23 & 4.5 & 0.1 & - \\
\hline 60 & 60 & 29 & 10 & 1.6 & - & - \\
\hline 80 & 45 & 11 & 0.2 & 0.3 & - & - \\
\hline
\end{tabular}

The formation model was then washed with a solution of ammonium carbonate salts with a volume concentration of $20 \%$. After each washing, the formation model was dried in an oven and the content of asphaltene sediments was determined by weight. For comparison, washing of another model formation was performed with formation water. The research results are shown in Table 5.

As can be seen from the table, the experiments were performed at temperatures of $20,40,60,80^{\circ} \mathrm{C}$, and the formation model was washed three times. Analysis of the research results shows that the formation water only after the third wash at a temperature of $80{ }^{\circ} \mathrm{C}$ allows cleaning the formation from asphaltene sediments. At lower temperatures, the washing efficiency is low.

The use of a $20 \%$ solution of ammonium carbon dioxide as a washing liquid shows that even at a temperature of $20^{\circ} \mathrm{C}$ after a single wash in the formation remains only $12 \%$ of asphaltene compounds. The efficiency of formation treatment increases with increasing temperature. From $40{ }^{\circ} \mathrm{C}$ begins the release of carbon dioxide, which, in turn, leads to increased purification of the pore space. At a temperature of $80^{\circ} \mathrm{C}$, the model formation is cleaned practically with ammonia water and carbon dioxide, which are formed during the decomposition of ammonium carbon dioxide salts.

\section{The results of industrial tests}

At the enterprises of GPD «PoltavaGasVydobuvannya» introduction of ammonium carbonate salts for treatment of the bottomhole zone of the formation was carried out. Investigations of wells after treatment were carried out on existing special research lines by the method of constant sampling in 5-6 modes of forward and 2-3 modes of reverse.

At the beginning of the test, the wells are flushed with $3-5 \%$ ammonia solution or ammonium bicarbonate, which are fed into the tubing or into the annulus. After that, the main intensification reagents are injected: ammonium carbonate salts.

The method of injection was chosen depending on the permeability of the collector. The working reagent was forced into the reservoir, kept there for 16-24 hours, then the well was developed in the barn and connected to the washing plant of complex gas treatment. After development and stabilization of the flow rate, the operating parameters of the well were removed.

The results of implementation showed that after treatment of productive reservoirs in wells № 23 of Opishnia and № 115 of Mashivka gas condensate fields $(\mathrm{GCF})$ an increase in gas flow was obtained from 10 to 33.8 thous. $\mathrm{m}^{3} /$ day and from 15 to 30.4 thousand $\mathrm{m}^{3} /$ day, 
and at well № 3 of Tymofiivka gas condensate field increase in gas production amounted to 80 thous. $\mathrm{m}^{3} /$ day (Table 6).

Thus, the effect of bottomhole zone treatment of the formation with ammonium carbonate salts was achieved due to the cleaning of the bottomhole zone of the formation and permeability increase of reservoir.

Another effect of well intensification with $\mathrm{NH}_{4} \mathrm{HCO}_{3}$ reagent is a significant increase in the condensate factor with some reduction in gas flow. Thus, at well № 56 of the Yablunivka gas condensate field, the condensate factor increased from 54.8 to $80.9 \mathrm{~kg} /$ thous. $^{3}$. The gas productivity after intensification decreased from 180 to $130-140 \mathrm{~kg} /$ thous. $^{3}$. In the second month of well operation, after treatment of the reservoir, an increase in gas flow was observed, which is 55 thous. $\mathrm{m}^{3} /$ day more than the initial values. Treatment of this well shows that the proposed reagent obviously increases the mobility of the condensate. The formation was hydrophilized with the displacement of liquid hydrocarbons from the pore channels, as evidenced by a sharp increase in condensate flow. After cleaning the reservoir, gas production was increased.

Table 6. Influence of intensification on well productivity.

\begin{tabular}{|l|c|c|c|}
\hline \multicolumn{1}{|c|}{ Period } & $\begin{array}{c}\text { Gas flow rate } \\
\boldsymbol{Q}_{g} \\
\text { thous. } \mathbf{m}^{\mathbf{3}} / \mathbf{d a y}\end{array}$ & $\begin{array}{c}\text { Condensate factor } \\
\boldsymbol{C F} \\
\mathbf{k g} / \text { thous. } \mathbf{~ m}^{\mathbf{3}}\end{array}$ & $\begin{array}{c}\text { Condensate flow rate } \\
\boldsymbol{Q}_{c}, \text { before treatment and } \\
\text { calculation without taking into } \\
\text { account } \boldsymbol{C F} \\
\mathbf{t} / \mathbf{d a y}\end{array}$ \\
\hline Before treatment & 14.7 & 69.1 & 1.01 \\
\hline After treatment & 95.14 & 69.1 & 6.6 \\
\hline 1 month & 90.6 & 69.1 & 6.2 \\
\hline 2 month & 50.6 & 69.1 & 3.5 \\
\hline 3 month & 15.0 & 69.1 & 1.03 \\
\hline
\end{tabular}

Table 7. Influence of intensification on well productivity.

\begin{tabular}{|c|c|c|c|c|c|}
\hline Period & $\begin{array}{c}\text { Gas flow rate } \\
Q_{g} \\
\text { thous.m }{ }^{3} / \text { day }\end{array}$ & $\begin{array}{c}\text { Condensate factor } \\
\text { CF } \\
\text { kg/thous. } \mathbf{m}^{3}\end{array}$ & $\begin{array}{c}\text { Condensate flow } \\
\text { rate } Q c \\
\text { before treatment } \\
\text { and calculation } \\
\text { without taking } \\
\text { into account } C F \\
\text { t/day }\end{array}$ & $\begin{array}{c}\text { Condensate flow } \\
\text { rate } Q_{c} \\
\text { after treatment } \\
\text { t/day }\end{array}$ & $\begin{array}{c}\text { Condensate } \\
\text { flow rate } \\
Q_{c} \\
\text { t/day }\end{array}$ \\
\hline \multicolumn{6}{|c|}{ Tymofiivka GCF, well № 58} \\
\hline Before treatment & 80.0 & 101 & 8.1 & - & - \\
\hline After treatment & 122.8 & 117 & 12.4 & 14.4 & 2.0 \\
\hline 1 month & 120.0 & 128 & 12.1 & 15.4 & 3.3 \\
\hline 2 month & 110.0 & 120 & 11.1 & 13.2 & 2.1 \\
\hline 3 month & 100.0 & 119 & 10.1 & 11.9 & 1.8 \\
\hline 4 month & 100.0 & 108 & 10.1 & 10.8 & 0.7 \\
\hline 5 month & 90.0 & 108 & 9.0 & 9.7 & 0.7 \\
\hline \multicolumn{6}{|c|}{ Yablunivka GCF, well № 108} \\
\hline Before treatment & 290 & 55 & 15.8 & - & - \\
\hline After treatment & 200 & 71 & 10.9 & 14.2 & 3.3 \\
\hline 1 month & 322 & 80 & 17.6 & 25.8 & 8.2 \\
\hline 2 month & 316 & 74 & 17.3 & 23.5 & 6.2 \\
\hline 3 month & 314 & 70 & 17.1 & 22.3 & 5.2 \\
\hline 4-6 months & 310 & 68 & 16.8 & 20.9 & 4.7 \\
\hline $7-9$ months & 307 & 60 & 16.0 & 18.6 & 2.6 \\
\hline 10 months & 290 & 55 & 15.9 & - & - \\
\hline
\end{tabular}

The most efficient is the treatment of wells № 58 of Tymofiivka and № 108 of Yablunivka gas condensate fields. The data given in Table 7 , indicate that in both wells after treatment increased gas flow rate and condensate factor. The gas flow rate gradually decreased to the initial values, while the condensate factor remains high.

The effectiveness of this treatment is obviously associated with the simultaneous cleaning of the bottomhole zone from asphalt-resinous contaminants and an increase in permeability, as well as with the hydrophilization of the pore space and an increase in the mobility of condensate precipitated as a result of exposure to carbon dioxide, which was released as a result of decomposition of ammonium carbonate.

\section{Conclusions}

1. Ammonium carbonate salts, in the absence of calcium chloride type waters, interact with carbonate rocks, 
increase the permeability of reservoirs due to the conversion of insoluble $\mathrm{CaCO}_{3}$ to soluble $\mathrm{Ca}\left(\mathrm{HCO}_{3}\right)_{2}$.

2. Ammonium carbonate salts have high displacing properties, the coefficient of displacement of kerosene with $\mathrm{NH}_{4} \mathrm{HCO}_{3}$ solution is $0.75-0.80$, while reservoir water $-0.55-0.58$.

3. The $\mathrm{NH}_{4} \mathrm{HCO}_{3}$ solution has good washing properties against asphaltene contaminants. So, after washing the reservoir with ammonium carbonate salts at a temperature of $20{ }^{\circ} \mathrm{C}$, no more than $10-12 \%$ of asphaltene substances remain in the model reservoir, and more than $60 \%$ with water.

4. Experimental and industrial tests at Opishnia, Mashivka, Tymofiivka, Yablunivka gas condensate fields of Poltava region confirmed the effectiveness of ammonium carbonate salts use for increasing hydrocarbon production. Industrial tests of ammonium carbonate salts showed an increase in gas flow by $30-50 \%$ at wells № 23 of Opishnia, № 115 of Mashivka, № 3 of Tymofiivka GCF, an increase in condensate factor by 22$35 \%$ at wells № 56 Yablunivka, № 58 of Tymofiivka GCR. The prospect of further research is aimed at developing a technology for increasing the production of liquid hydrocarbons by using ammonium carbonate salts.

\section{References}

1. Puhach, V.: Teoretychni zasady staloho nadrokorystuvannia ( Theoretical basis of sustainable subsoil use). Environmental Economics and Sustainable Development, 45-48 (2014) http://ecops.kiev.ua/files/2014/15_PUHACH.pdf

2. Pysmennyi, S., Fedko, M., Shvaher, N., Chukharev, S.: Mining of rich iron ore deposits of complex structure under the conditions of rock pressure development. E3S Web of Conf. 201, 01022 (2020). doi: 10.1051/e3sconf/202020101022

3. Shvaher, N., Komisarenko, T., Chukharev, S., Panova S.: Annual production enhancement at deep mining. E3S Web of Conf. 123, 01043 (2019). doi.: 10.1051/e3sconf/201912301043

4. Li, G., Tang, B., Meng, Y.-F., Wei, N., Li, Y.-J., Wang, G.-F.: Analysis of retrograde condensation behavior and impacts of gas-condensate reservoirs gas drilling: A case study of gas-condensate reservoir in block D. Nat. Gas Geosci. 25(10), 1615-1619 (2014). doi: $\quad 10.11764 /$ j.issn.16721926.2014.10.1615

5. Paredes, J.E., Perez, R., Larez, C.J.: Correlation To Predict and Validate the Maximum Retrograde Condensation in Gas Condensate Reservoirs. (Society of Petroleum Engineers, 2012), https:/www.onepetro.org/conference-paper/SPE158494-MS. Accessed 1 January 2012

6. Wang, Z., Zhu, S., Zhou, W., Liu, H., Hu, Y., Guo, P., Du, J., Ren, J.: Experimental research of condensate blockage and mitigating effect of gas injection. Petroleum 4(3), 292-299 (2018). doi.: 10.1016/j.petlm.2018.03.008
7. Joonaki, E., Hassanpouryouzband, A., Burgass, R., Hase, A., Tohidi, B.: Effects of Waxes and the Related Chemicals on Asphaltene Aggregation and Deposition Phenomena: Experimental and Modeling Studies. ACS omega 5(13), 7124-7134 (2020). https://doi.org/10.1021/acsomega.9b03460

8. Azevedo, L.F.A., Teixeira, A.M.: A Critical Review of the Modeling of Wax Deposition Mechanisms. Pet Sci Technol 21(3-4), 393-408 (2003). doi.: 10.1081/LFT-120018528

9. Theyab, M.A.: Wax deposition process: mechanisms, affecting factors and mitigation methods. Open

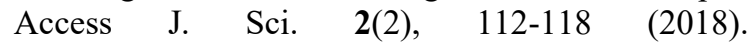
doi: 10.15406/oajs.2018.02.00054

10. Babadagli, T.: Development of mature oil fields A review. J. Pet. Sci. Eng. 57(3-4), 221-246 (2007). doi.: 10.1016/j.petrol.2006.10.006.

11. Thomas, S.: Enhanced Oil Recovery - An Overview. Oil Gas Sci. Technol. 63(1), 9-19 (2007). doi: 10.2516/ogst:2007060

12. Parker, M.E., Meyer, J.P., Meadows, S.R.: Carbon Dioxide Enhanced Oil Recovery Injection Operations Technologies. Energy Procedia 1(1), 3141-3148 (2009). doi: 10.1016/j.egypro.2009.02.096

13. Perera, M.S.A., Gamage, R.P., Rathnaweera, T.D., Ranathunga, A.S., Koay, A., Choi, X.: A Review of $\mathrm{CO}_{2}$-Enhanced Oil Recovery with a Simulated Sensitivity Analysis. Energies 9, 481 (2016). doi.: 10.3390/en9070481

14. Mansour, E.M., Al-Sabagh, A.M., Desouky, S.M., Zawawy, F.M., Ramzi, M.: A laboratory investigation of carbon dioxide-enhanced oil recovery by focusing on $\mathrm{CO}_{2}$-oil physical properties. Egypt. J. Pet. 28(1), 21-26 (2019). doi.: 10.1016/j.ejpe.2018.10.004.

15. Bennion, D.B., Thomas, F.B.: The use of carbon dioxide as an enhanced recovery agent for increasing heavy oil production. Paper presented at the Joint Canada/Romania heavy oil symposium, Alberta Oil Sands Technology and Research Authority, Sinaia (Romania), 7-13 Mar 1993

16. Heddle, G., Herzog, H., Klett, M. (eds): The economics of $\mathrm{CO}_{2}$ storage (Massachusetts Institute of Technology, USA, 2003).

17. Truhina, O.S., Sintsov, I.A.: Opyit primeneniya uglekislogo gaza dlya povyisheniya nefteotdachi plastov. (Experience of using carbon dioxide for enhanced oil recovery). Uspehi sovremennogo estestvoznaniya. 3, 205-209 (2016). URL: http://www.naturalsciences.ru/ru/article/view $?$ id $=35849$

18. Dmytrenko, V., Zezekalo, I.: Vplyv vuhlekyslotnykh solei amoniiu na filtratsiini vlastyvosti porid pryvybiinoi zony plasta (Influence of carbonic acid ammonium salts on the filtration properties of bottom-hole formation zone ). Prospecting and Development of Oil and Gas Fields 1(70), 70-76 (2019). doi: https://doi.org/10.31471/1993-99732019-1(70)-70-76 
19. McBride-Wright, M., Maitland, G.C., Trusler, J.P.M.: Viscosity and Density of Aqueous Solutions of Carbon Dioxide at Temperatures from (274 to 449) K and at Pressures up to $100 \mathrm{MPa}$. J. Chem. Eng. Data 60(1), 171-180 (2015). doi.: $10.1021 /$ je 5009125 